\title{
PEMENUHAN HAK-HAK KAUM DIFABEL DALAM KERANGKA HAK AZASI MANUSIA
}

\author{
Fajar $^{1}$ \\ Dosen Fakultas Syari'ah dan Hukum Islam \\ Institut Agama Islam Negeri (IAIN) Bone \\ Jl. Hos Cokroaminoto, Watampone, Kabupaten Bone, Indonesia. \\ Email: ${ }^{1}$ fajarphilosophy@gmail.com
}

\begin{abstract}
This study describes the rights of persons with disabilities in the eyes of human rights. Nowadays, the disabled are positioned as second-class people whose rights are often neglected, both from the aspect of policy as well as state development. The state and society as a totality of structures are ignorant in presenting a space that accommodates the rights of people with disabilities based on diversity of every human ability. Therefore, the problems of people with disabilities can be resolved by the approach of social welfare or compassion as a result of the failure of the state to see the core issuesof the diffable holistically. Therefore, in the future there should be a special institution in the form of the Commission for the Protection of the Rights of People with Disabilities (KPHD) to resolve the complexity of disability issues in terms of social, cultural, educational, legal, and political aspects.
\end{abstract}

Keywords: Fulfilment of rights, diffable, Human Rights.

\begin{abstract}
Abstrak
Kajian ini menjelaskan tentang hak-hak kaum difabel atau disabilitas dalam kacamata Hak Azasi Manusia (HAM). Dimana selama ini kaum difabel diposisikan sebagai masyarakat kelas dua yang seringkali terabaikan hak-haknya, baik dari aspek kebijakan maupun dari aspek pembangunan negara.Negara dan masyarakat sebagai satu totalitas struktur abai dalam menghadirkan suatu ruang yang mengakomodir hak-hak kaum difabel yang didasarkan pada keragaman kemampuan setiap manusia atau difabilitas. Sehingga permasalahan kaum difabel seringkali diselasaikan dengan pendekatan kesejahteraan sosial atau belas kasih sebagai akibat dari kegagalan negara melihat inti permasalahan difabel secara holistik. Oleh karena itu, kedepannya semestinya ada lembaga khusus berupa Komisi Perlidungan Hak-hak Kaum Difabel (KPHD) untuk menyeselaikan kompleksitas permasalahan difabel baik dari sisi sosial, budaya, pendidikan, hukum, maupun politik.
\end{abstract}

Kata kunci: Pemenuhan hak, Difabel, HAM. 


\section{PENDAHULUAN}

Berubahnya paradigma pembangunan Nasional ke arah demokratisasi dan desentralisasi, menumbuhkan kesadaran yang luas tentang perlunya peran serta masyarakat dalam keseluruhan proses pembangunan. Partisipasi dan pemenuhan hak-hak sipil muncul sebagai dua kata yang banyak diungkapkan ketika berbicara tentang demokrasi. Paradigma demokrasi meniscayakan pemenuhan Hak Azasi Manusia (HAM), dimana kebebasan dan persamaan hak dalam ruang publik menjadi basis untuk meningkatkan partisipasi masyarakat untuk memperjuangkan hak-haknya dalam berbagai sektor kehidupan. Melalui tatanan demokrasi dengan semangat inklusi dan partisipasi yang ada di dalamnya, sangat memungkinkan mewujudkan hak-hak dan partisipasi penuh masayarakat di dalam ruang publik, untuk mendorong terciptanya masyarakat yang berdaya saing serta mandiri secara sosial, ekonomi, budaya, dan politik.

Tatanan demokrasi yang berorientasi pada inklusi, sangat dibutuhkan sebagai instrumen pemberdayaan masyarakat sipil (civil society). Karena berdayanya civil society memiliki koherensi terhadap tegaknya fungsi HAM. Sedangkan pengakuan terhadap HAM, membawa konsekuensi nyata akan adanya pengakuan terhadap kebebasan, persamaan, dan keadilan bagi seluruh warga negara tanpa ada pengecualian sedikit pun. Termasuk dalam hal ini pemenuhan hak-hak kaum difabel dalam arena publik.

Pemenuhan hak-hak kaum difabel serta seluruh warga negara dalam makna HAM, pada dasarnya adalah bagian dari upaya untuk membentuk suasana kemanusiaan yang adil dan bermartabat. Dalam konteks hari ini, tidak sedikit untuk tidak mengatakan masih banyak kebijakan pemerintah yang belum menyentu seluruh lapisan masyarakat secara holistik, dan tentunya tidak salah jika dikatakan kebijakan itu masih diskiriminatif. Salah satu kelompok masyarakat yang seringkali terabaikan hak-haknya oleh pemerintah adalah kaum difabel. Sampai saat ini kaum difabel masih menjadi masyarakat kelas dua, yang selalu menjadi korban diskriminasi secara sosio-kultural mapaun secara politik. Alienasi serta subordinasi kaum difabel secara sosio-kultural seringkali ditemui dalam kehidupan sehari-hari, ditambah kebijakan pemerintah yang juga seringkali 
diskiriminatif serta bias normalitas-difabilitas. Dalam artian kabijakan pemerintah belum menyentu secara universal aspek-aspek difabilitas yang notabene menjadi harapan dan cita-cita kaum difabel.

Kajian tentang pemenuhan hak-hak kaum difabel dalam konteks HAM menjadi sengat relevan dan menarik. Tujuannya tidak hanya untuk memberikan penjelasan normatif, melainkan untuk memberikan peta jalan untuk melepaskan kaum difabel dari diskriminasi yang selama ini mereka alami. Untuk itu, penelitian ini difokuskan pada pemenuhan hak-hak kaum difabel dalam konteks HAM. Wacana HAM sebagai dasar gerakan kaum difabel, dipahami sebagai wacana yang berorientasi pada perubahan struktur sosial, budaya dan politik. Agar masyarakat dan negara sebagai totalitas struktur adaptif terhadap visi kesetaraan dan pemenuhan hak-hak kaum difabel dalam segala sektor kehidupan publik.

\section{PEMBAHASAN}

\section{Kontestasi Makna Disabilitas}

Pemenuhan hak-hak warga disabilitas dalam konstruksi HAM, perlu kiranya dijelaskan terlebih-dahulu bebarapa paradigma dan pendekatan dalam memahami wacana disabilitas (difabilitas). Secara garis besar, ada tiga konsepsi dalam perkembangan sejarah perubahan sosial serta penteorian disabilitas yang cukup dominan, yaitu pendekatan medikal model dan sosial model. Sedang dalam konteks Indonesia adalah pendekatan difabilitas.

\section{a. Pendekatan Medical Model}

Pandangan medis individual, yang melihat dan menempatkan kecacatan sebagai sebuah permasalahan individu. Secara ringkas, pandangan ini menganggap impairment (kecacatan) sebuah tragedi personal. Impairment selalu diposisikan sebagai akar permasalahan serta penyebab atas hambatan aktifitas serta berbagai bentuk ketidakberuntungan sosial yang dialami. ${ }^{1}$

Switzer seperti dikutip Ishak Salim, perspektif medis memandang bahwa persoalan yang disebabkan oleh 'disabilitas' dianggap berada dan bersumber

\footnotetext{
${ }^{1}$ Joni Yulianto, “Terminologi: Difabel atau Penyandang Disabilitas”, dalam M.Syafi'ie, dkk, Potret Difabel Berhadapan dengan Hukum Negara (Yogyakarta: Sigab, 2014), h. 6
} 
dalam diri individu tersebut dan terlepas dari konteks sosial, atau mengidentifiasi difabel sebagai masalah biologis. Tujuannya bagi difabel kemudian adalah untuk menemukan obat medis demi menyembuhkan 'kecacatannya'.Secara bersamaan, perspektif ini fokus pada disabilitas sebagai sebuah masalah yang dapat ditangani melalui kemajuan medis dan teknologi. ${ }^{2}$

Kelompok difabel adalah korban kuasa diskursus medis. Kedudukan profesional medis (dokter), menurut Foucault, memang memiliki kedudukan istimewa dibanding yang lain atau peradaban manapun. Menyandang status ini adalah orang tidak bisa terdeferensiasi atau bertukar tempat (interchangeable). Pernyataan medis tidak dikeluarkan oleh sembarang orang; nilai pernyataanpernyataan tersebut, keampuhan, kekuatan terapi yang dimilikinya. Eksistensinya sebagai pernyataan-pernyataan medis tidak bisa dipisahkan dari status-status yang dimiliki orang tertentu yang punya hak untuk mengeluarkan pernyataanpernyataan itu, seperti siapa yang sakit, rasa sakit atau kematian. ${ }^{3}$

Bahasa (ucapan) professional medis ini mengandung kuasa karena pada dirinya melekat modalitas simbolik, jadi ucapannya memiliki nilai kuasa yang berorientasi pada "kebenaran". Untuk menjelaskan bahasa sebagai alat kekuasaan, Bourdieu sebagaimana dikutip Yasraf A. Piliang menggunakan istilah kompetensi, yang bermakna bahwa orang yang mempunyai kecakapan dan otoritas untuk berbicara, menafsirkan, menilai, atau melegitimasi bahasa. Kompetensi ini biasanya dikaitkan dengan kepemilikan apa yang disebut Bourdieu sebagai modalitas simbolik. Artinya, semakin besar seseorang (kelompok orang, negara) modal simbolik, semakin besar otoritasnya dalam menentukan arah pasar simbol. ${ }^{4}$ Modalitas simbolik itu melekat pada diri professional medis modalitas itu pun memberikan otoritas kepadanya untuk menilai siapa yang sakit dan tidak sakit, serta menilai siapa yang cacat dan tidak cacat. Akhirnya mewujud menjadi

\footnotetext{
${ }^{2}$ Ishak Salim, "Perspektif Disabilitas dalam Pemilu 2014 danKontribusi Gerakan Difabel Indonesia bagiTerbangunnya Pemilu Inklusif di Indonesia”, (Jurnal The Politics, Vol. 1, No. 2, Juli 2015), h. 131.

${ }^{3}$ Michel Foucault, Arkeologi Pengetahuan (terj. Inyiak Ridwan Muzir, Yogyakarta: IRCiSoD, 2012), h. 100.

${ }^{4}$ Yasraf A. Piliang, Transpolitika: Dinamikan Politik di dalam Era Virtualitas (Yogyakarta: Jalasutra, 2005), h. 202.
} 
kebenaran yang diyakini dan dibatinkan, disitulah praktik kuasa dalam pewacanaan ilmu pengetahuan dipermainkan.

Peranan kuasa medis cukup sentral dan ekslusif dalam menentukan standar-standar tentang normalitas dan disabilitas (penyandang cacat), selanjutnya standar-standar medis tersebut kemudian melahirkan pelabelan siapa yang cacat dan siapa yang normal. Pelabelan sosial yang melahirkan semiotika sosial (pemaknaan sosial), berdampak pada persepsi atau konsepsi seseorang dalam melihat disabilitas. Tindakan yang mengeksklusi kelompok disabilitas pun lahir dalam praktik sosial dan akhirnya menjadi kebiasaan sosial yang membudaya. Dikatakan membudaya karena telah menjadi pemahaman yang laten atau terpola dalam kebiasaan sosial dan praktik sosial yang berulang dalam lintasan ruang dan waktu.

Implikasi dari paradigma medical model adalah institusionalisasi disabilitas dengan didirikannya lembaga-lembaga atau panti-panti sosial dan panti rehabilitasi untuk memampukan kembali/menormalkan, sebagai pendekatan utama dalam mengatasi permasalahan disabilitas. Penyandang disabiltas dianggap sebagai center of the problem, dan ketidakberfungsian dan kerusakan fungsi fisik atau mental yang terjadi pada individu disabilitas dianggap sebagai penyebab utama yang membutuhkan penyembuhan atau perbaikan. Namun yang menjadi problem, tanpa sadar sebagian besar kelompok disabilitas menerima diri mereka sebagai kelompok yang kurang mampu (tidak normal). Sehingga tidak mampu melihat wajah institusionalisasi tersebut sebagai sebuah kekerasan simbolik dan diskriminasi yang berupaya meminggirkan mereka dari dunia sosial yang seharusnya mereka juga ada di dalamnya bersama warga masyarakat lainnya.

Kekerasan simbol, menurut Bourdieu seperti dikutip Yasraf, adalah sebuah bentuk kekerasan yang halus dan tidak tampak yang menyembunyikan dibaliknya pemaksaan dominasi. Kekerasan simbol bukanlah sekedar bentuk dominasi melalui bahasa dan (media) komunikasi; ia adalah penggunaan dominasi sedemikian rupa, sehingga dominasi tersebut diakui sebagai legitimate. ${ }^{5}$

${ }^{5}$ Yasraf A. Piliang, Transpolitika: Dinamikan Politik, h. 200-201. 
Kekerasan simbol terhadap kelompok difabel berlangsung melalui pelabelan, sistem tanda, simbol, dan interpretasi atasnya yang semuanya berujung pada pemahaman yang laten dan menstruktur menjadi sebuah budaya dan praktik sosial politik yang segregatif, yaitu peminggiran kaum difabel dalam arena publik.

Menurut Yasraf, kekerasan simbol menciptakan sebuah mekanisme sosial yang di dalamnya relasi bahasa (language relation) saling bertautan dengan relasi kekuasaan. Sebuah sistem kekuasaan berupaya melanggengkan posisi dominan kelompok tertentu dengan cara mendominasi dan mendistorsi bahasa yang digunakan dalam komunikasi. Sehingga yang dikembangkan adalah prinsip monosignification dan monosemy pertandaan dan pemaknaan serba tunggal. ${ }^{6}$ Pemaknaan tunggal terhadap disabilitas di praktikkan oleh profesional medis, melalui serangkaian standar keilmuan yang sepihak tanpa melihat faktor lain yang membuat kelompok disabilitas menjadi tidak mampu menjalani kehidupan sosial sebagaiamana kelompok masyarakat pada umumnya.

Kekerasan simbol terjadi ketika orang yang didominasi menerima sebuah simbol (konsep, gagasan, ide, kepercayaan, prinsip) dalam bentuknya yang terdistorsi dan memberikan pengakuan atas apa yang diterima secara disrtortif tersebut, untuk kemudian menggiring mereka menerapkan kriteria evaluasi dominan yang telah terdistorsi tersebut, dalam menilai diri dan kehidupan mereka sendiri. Proses dominasi tersebut, sebetulnya terjadi sebuah bentuk pemaksaan simbolik yang sangat halus, akan tetapi orang yang didominasi tidak menyadari adanya pemaksaan atau menerima pemaksaan tersebut sebagai commonsense. ${ }^{7}$ Secara simbolik pelembagaan dan institusionalisasi kelompok difabel dalam bentuk panti sosial dan rehabilitasi individu adalah sebuah bentuk kekerasan simbolik yang diterima warga difabel sebagai suatu bentuk kebenaran tunggal. Kesadaran kritis mereka tersandera oleh wacana dominan yang di praktikkan oleh kaum medis tersebut.

Benny H. Hoed menyatakan, tanpa sadar, masing-masing secara bersamaan mengikuti warga lainnya dalam memberikan makna tertentu kepada

${ }^{6}$ Yasraf A. Piliang, Transpolitika: Dinamikan Politik, h. 201.

${ }^{7}$ Yasraf A. Piliang, Transpolitika: Dinamikan Politik, h. 201-202. 
orang lain, yakni realitas sosial budaya disekitar. Inilah yang terjadi dalam kehidupan sosial sehari-hari dari zaman ke zaman. Gejala inilah yang disebut semiotika sosial, yakni makna yang terbentuk dalam masyarakat tentang berbagai realitas sosial budaya. ${ }^{8}$ Label "penyandang cacat" menciptakan semiotika sosial budaya yang membentuk makna atau konotasi negatif terhadap difabel, yakni, kekurangan, ketidakmampuan dan ketidakberfungsian fisik dan mental. Tentunya label negatif ini secara geneologis selain bersumber dari nilai budaya masyarakat tertentu, juga bersumber dari pandangan medis yang bias normalitas, yang mayoritas dianggap normal, sedangkan yang minoritas atau yang berbeda dianggap tidak normal atau cacat. Akhirnya kecacatan itu diterima sebagai kenyataan sosial (fakta sosial).

Disinilah awal mula dimulainya praktik segregasi dan eksklusi kelompok difabel, seperti contoh institusionalisasi difabel melalui panti-panti rehabilitasi, pemisahan difabel dalam institusi pendidikan melalui sekolah khusus semisal Sekolah Luar Biasa (SLB), penerimaan masyarakat dalam kehidupan sosial terhadap difabel lebih negatif, dan celakanya keluarga difabel pun ikut melakukan praktik eksklusi karena adanya rasa malu memiliki anak difabel.

\section{b. Pendekatan Social Model}

Barton seperti dikutip Ro'fah, dalam upaya untuk melemahkan dominasi pendekatan medis dan individu dalam dunia disabilitas, dibutuhkan hampir satu abad. Baru pada dekade 1960-an seiring dengan munculnya gerakan masyarakat sipil diberbagai belahan Amerika dan Eropa. Kelompok-kelompok difabel mulai mengkritisi bahwa model individual telah cukup lama meminggirkan peran mereka dari kehidupan masyarakat. Asumsi-asumsi model individual yang menganggap difabel adalah individu yang kurang dan tidak bisa menjalankan peran penuh dalam masyarakat telah melahirkan opresif dari ketakutan sampai over-proteksi dan kebijakan serta layanan yang parsial. $^{9}$ Kritik-kritik ini

${ }^{8}$ Benny H. Hoed, Semiotik dan Dinamika Sosial Budaya (Depok: Komunitas Bambu, 2011), h. 176.

${ }^{9}$ Ro'fah, "Teori Disabilitas: Sebuah Review Literatur" dalam Kamil Alfi Arifin (ed.), Analekta Difabilitas: Sumbangsih untuk Pengayaan Rancangan Undang-undang Difabilitas (Jurnal DIFABEL, Sasana Integrasi dan Advokasi Difabel (SIGAB), Vol. 2, No. 2, Tahun 2015), h. 146 . 
melahirkan apa yang disebut social model of disability atau model sosial disabilitas yang mengubah fokus pembahasan disabilitas dari isu individu ke isu sosial dan politik. ${ }^{10}$

Konseptualisasi disabilitas yang terlahir atas dominasi konsepsi disabilitas dan bagaimana semestinya lingkungan sosial memandang diri mereka. Pandangan ini disebut dengan social model, yang belakangan kemudian berkembang menjadi pandangan yang melihat disabilitas dalam pendekatan HAM, pendekatan ini dibangun atas sebuah prinsip dasar bahwa kecacatan/impairment maupun keterbatasan fungsional sesungguhnya tidak pernah mempunyai korelasi langsung terhadap apa yang dikatakan sebagai disabilitas/ketidakmampuan aktifitas, maupun juga partisipasi sosial. ${ }^{11}$

Model sosial mengubah arah permasalahan difabel dari kekurangan fungsional, psikologis dan kognitif yang dimiliki individu kepada struktur masyarakat. Secara sistematis menindas dan mendiskriminasi terhadap difabel serta perilaku negatif masyarakat yang harus dialami oleh difabel setiap hari. Dengan kata lain, persolan disabilitas terletak pada faktor yang labih luas dan bersifat eksternal yakni lingkungan sosial, dan bukan konsekuensi dari kekurangan fisik atau mental individu. ${ }^{12}$

Jika diamati, landasan teori yang digunakan oleh model sosial sangat diwarnai oleh ideologi Marxis dan Strukturalis. Pemisahan antara impeirment dan disability yang dimunculkan UPIAS merupakan analisa dengan kacamata materialisme yang mengasumsikan bahwa konstruksi sosial bagi individu yang mengalami impairment berawal dari bagaimana masyarakat mengorganisir akitivitas-aktivitas materialnya.

Siebers seperti dikutip Ishak, perspektif sosial kontras dengan perspektif medis, perspektif sosial memandang disabilitas seseorang (dan bukan kecacatannya) lebih sebagai akibat dari faktor eksternal yang dikenakan pada seseorang daripada sekadar fungsi biologis difabel. Perspektif sosial

\footnotetext{
${ }^{10}$ Ro'fah, “Teori Disabilitas: Sebuah Review Literatur”, h. 146.

${ }^{11}$ Ro'fah, “Teori Disabilitas: Sebuah Review Literatur”, h. 9.

${ }^{12}$ Ro'fah, “Teori Disabilitas: Sebuah Review Literatur”, h. 147.
} 
memungkinkan untuk melihat disabilitas sebagai efek dari lingkungan eksternal yang tidak bersahabat bagi sejumlah bentuk tubuh dan bukan hal yang lain. Untuk itu difabel lebih membutuhkan kemajuan dalam keadilan sosial dan bukan dalam kemajuan kedokteran. Keyakinan-keyakinan dan fungsi-fungsi sosial yang kemudian meminggirkan dan melemahkan peran difabel dapat dilihat sebagai hambatan untuk hidup sepenuhnya bersandar pada jenis kemampuan mereka. ${ }^{13}$

Dengan dimikian, fokus perhatian untuk melihat persoalan difabel bukan pada person melainkan pada masyarakat sebagai suatu sistem. Apabila paradigma medis menganggap individu sebagai sumber masalah, maka paradigma sosial model lebih melihat sumber permasalahan dari struktur masyarakatnya. Jadi yang sakit bukan individunya, melainkan masyarakat sebagai satu sistem sosial. Pandangan sosial ini menaruh perhatian pada struktur dan sistem sosial sebagai pusat permasalahan. Pandagan ini menunjukan, kecacatan tidaklah bersumber dari kelemahan individual, melainkan bersumber dari struktur dan institusi sosial dalam masyarakat yang tidak menggambarkan distribusi penguasaan resources dan penguasaan fasilitas serta berbagai sarana sosial yang tidak merata.

Pergeseran makna dari medical model ke social model amat penting, karena ada upaya untuk menggugat perspektif yang sebelumnya sangat dominan. Memahami dan mendefinisikan "kecacatan” sebagai persoalan individu medis, menuju persepsi baru yang lebih menilai "kecacatan" sebagai permasalahan sosial dan politik. Maksudnya, masalah "kecacatan" tidak dapat "semena-mena" menjadi urusan kuasa medis yang men-judge seseorang sebagai "orang cacat" akan tetapi kecacatan itu sendiri merupakan pertarungan makna dalam masyarakat. Sehingga "cacat" merupakan sebuah konstruksi sosial, dan setiap konstruksi merupakan kekaburan yang dipaksakan menjadi benar. ${ }^{14}$

Disabilitas, menurut pandangan ini dikarenakan atas kegagalan masyarakat, lingkungan serta negara dalam mengakomodasi apa yang menjadi

\footnotetext{
${ }^{13}$ Ishak Salim, "Perspektif Disabilitas dalam Pemilu 2014 danKontribusi Gerakan Difabel Indonesia bagiTerbangunnya Pemilu Inklusif di Indonesia”, h. 132.

${ }^{14}$ Ro'fah Mudzakir dan Slamet Thohari, 2010, “Kaum Difabel dalam Pergulatan Makna: Sekilas Pergeseran Persepsi Disability dan Relevansinya di Indonesia", dalam Sahiron dan Asep Jahidin (ed.), Ontologi Pekerjaan Sosial, Yogyakarta: UIN Sunan Kalijaga, h. 65.
} 
kebutuhan penyandang disabilitas. Dengan kata lain, disabilitas yang dimaksud merupakan buah dari sebuah interaksi lingkungan yang gagal mengakomodasi penyandang disabilitas. ${ }^{15}$ Singkatnya kecacatan merupakan akibat dari konstruksi sosial dan struktur sosial yang bias normalitas.

Dari konsepsi sosial model inilah HAM kemudian terintegrasi dengan isuisu disabilitas sebagai sebuah bagian integral atas isu HAM, dimana berangkat dari salah satu prinsip bahwa hak asasi manusia merupakan hak yang secara inheren melekat pada setiap manusia, maka kondisi social exclusion yang dialami oleh kelompok penyandang disabilitas yang diakibatkan atas interaksi yang gagal tersebut sudah seharusnya dipandang sebagai suatu bentuk pelanggaran HAM. Dengan kata lain, jaminan atas kesetaraaan, kesamaan hak serta partispasi penuh juga semestinya melekat pada setiap individu penyandang disabilitas yang juga mesti dilindungi.

Untuk aksi politik gerakan difabel social model-lah yang melahirkan gerakan hak dfabel (Disability Right Movement) dengan tuntutan perubahan sistem dan struktur yang selama ini dianggap gagal mengakomodasi difabel. Hal ini memunculkan tuntutan perubahan strategi negara terhadap difabel dari pemenuhan kebutuhan khusus difabel yang diberikan melalui program-program sosial dalam welfare state dan pendekatan-pendekatan yang berbasis karitas kepada kesamaan hak akan akses. ${ }^{16}$

Melihat aksi dan praktik sosial yang dikembangkan oleh kaum difabel, tidak salah jika penulis mengatakan bahwa preferensi kaum difabel dalam memandang kecacatan lebih kepada pendekatan kedua, yaitu sosial model. Kaum difabel melihat kecatatan ini sebagai hasil dari konstruksi sosial, yakni kecacatan bersumber dari pelabelan, lingkungan sosial yang tidak aksesibel. Lain kata adalah kegagalan masyarakat, lingkungan sosial, dan negara selaku pemegang kebijakan dalam mengakomodasi kebutuhan kelompok disabilitas.

\footnotetext{
${ }^{15}$ Ro'fah Mudzakir dan Slamet Thohari, 2010, "Kaum Difabel dalam Pergulatan Makna: Sekilas Pergeseran Persepsi Disability dan Relevansinya di Indonesia”, h. 10.

${ }^{16}$ Ro'fah Mudzakir dan Slamet Thohari, 2010, "Kaum Difabel dalam Pergulatan Makna: Sekilas Pergeseran Persepsi Disability dan Relevansinya di Indonesia”, h. 77.
} 
Aktor-aktor difabel sebagai agensi lebih ke faktor sosial dalam memandang sumber kecacatan itu, tindakannya pun terhadap kaum difabel, lebih mengedapankan nilai-nilai HAM dan demokrasi. Membangun kesetaraan bagi kaum difabel serta pemberdayaan difabel dalam rangka meningkatkan partisipasi difabel dalam ruang publik secara cerdas dan mandiri. Dengan begitu kelompok difabel diharapkan menemukan makna dan eksistensinya sebagai manusia, yang sudah selayaknya memiliki kuasa dan kebebasan atas dirinya sendiri, serta menentukan nasibnya sendiri tanpa ada eksklusi dan diskriminasi padanya, baik diskriminasi secara sosial maupun secara struktural.

\section{c. Pendekatan Difabilitas}

Di Indonesia konsepsi kecacatan/difabilitas pun terus berkembang. Di era tahun 90-an, ketika para aktivis difabel mulai menggagas penolakan atas istilah dan pemaknaan istilah penyandang cacat, yang sampai akhirnya memunculkan istilah "difabel" sebagai akronim dari differently abled people yang dimaknai dengan "orang yang memiliki kemampuan berbeda". Pertama kali digagas oleh Mansour Faqih dan Setya Adi Purwanta (seorang difabel netra) bukanlah serta merta pengganti dari istilah penyandang cacat. Gagasan atas ditawarkannya pengistilahan ini adalah lebih merupakan ide atas perubahan konstruksi sosial memahami difabilitas, atau yang saat itu dikenal sebagai kecacatan/penyandang cacat. ${ }^{17}$ Istilah difabel-difabilitas digunakan kaum disabilitas saat ini sebagai jalan untuk mempejuangkan hak-hak kelompoknya di dalam ruang publik.

Baik istilah penyandang cacat maupun penyandang disabilitas merupakan istilah yang sudah pernah dipakai dalam kebijakan setingkat Undang-Undang. Misalnya UU penyadangan cacat dan UU ratifikasi Konvensi Hak-hak Penyandang Disabilitas. Sementara istilah difabel merupakan wacana tanding atas istilah penyadang cacat. Istilah penyadang cacat sangat lazim diucapkan dimasa lalu. Khsususnya setelah pemerintah Orde Baru menggunakan istilah penyadang cacat dalam nomenklatur hukum dan politik dengan memuatnya dalam satu UU khusus, yakni UU No. 4 Tahun 1997 tentang Penyandang Cacat. Istilah ini

\footnotetext{
${ }^{17}$ Ro'fah Mudzakir dan Slamet Thohari, 2010, "Kaum Difabel dalam Pergulatan Makna: Sekilas Pergeseran Persepsi Disability dan Relevansinya di Indonesia", h. 11-12.
} 
dipakai dengan asumsi medis yang kental yang menganggap sebagai tubuh yang tak lengkap adalah sebuah kerusakan fisik dan fisiologis. Kerusakan itulah yang kemudian disebut cacat, sebagaimana istilah ini sering dipakai untuk barang yang rusak. Kerusakan tentu saja bermakna sakit dalam dunia medis atau kesehatan. ${ }^{18}$

Melihat pergeseran makna dari penyandang cacat, penyandang ketunaan, penyandang disabilitas, dan terakhir "difabel”, penulis menilai itu sebagai upaya kelompok disabilitas untuk melawan stigmatisasi dan steriotipe negatif yang dialami selama dalam kehidupan sosial. Istilah difabel diperlukan untuk mengubah stigmatisasi negatif dari "penyandang cacat" yang berkonotasi ketidakmampuan fisik dan mental, menjadi "difabel" yang dikonotasikan sebagai orang yang mampu dengan cara yang berbeda. Artinya, istilah difabel dianggap lebih adil dan representatif.

Istilah difabel diwacanakan untuk menekankan bahwa orang-orang yang memiliki sebagian anggota tubuh yang berbeda dengan orang lain bukanlah orang-orang yang tidak memiliki kemampuan untuk berkarya. Orang-orang ini diakui memiliki kemampuan untuk melakukan sesuatu sebagaimana orang lain, namun dengan cara yang berbeda. Jika orang-orang yang memiliki tangan melukis dengan tangannya, maka orang-orang yang tidak memiliki tangan tetap mampu melukis tetapi dengan menggunakan kaki atau mulutnya. Perubahan penyebutan dari disability menjadi diffable (diffability) bukan hanya perubahan istilah belaka. Namun, ada makna sangat dalam yang terkandung di dalamnya, yaitu pengakuan akan kemampuan dimiliki oleh orang-orang yang memiliki bentuk tubuh berbeda. Perubahan ini dilakukan untuk secara bertahap mengubah stigma yang dibangun oleh masyarakat "normal", bahwa kaum "cacat" tidak memiliki manfaat bagi kehidupan dan hanya menjadi beban bagi kaum "normal". ${ }^{19}$

Pengistilahan difabel mencoba melepaskan hubungan kausatif antara keterbatasan fungsi (fisik dan mental), hambatan aktifitas, serta ketidakberuntungan sosial. Tiga hal tersebut boleh jadi berkaitan namun bukan

\footnotetext{
${ }^{18}$ Ishak Salim, "Perspektif Disabilitas dalam Pemilu 2014 danKontribusi Gerakan Difabel Indonesia bagiTerbangunnya Pemilu Inklusif di Indonesia”, h. 244.

${ }^{19}$ Asyhabuddin, "Difabilitas dan Pendidikan Inklusif: Kemungkinannya di STAIN Purwokerto," (Jurnal INSANIA, P3M STAIN Purwokerto, Vol. 13, No. 3, Sep-Des 2008), h. 2-3.
} 
merupakan keterkaitan yang mutlak. Konsepsi difabilitas mengakui bahwa setiap individu mempunyai perbedaan, dan sebagai konsekuensi dari perbedaan itulah, maka sangat penting bagi lingkungan dan masyarakat untuk merespon positif bentuk perbedaan tersebut. Konsepsi ini juga mengakui realitas akan keterbatasan fungsi (fisik atau mental) sebagai suatu realitas yang normal. ${ }^{20}$

Konsepsi ini juga menggeser standar normalisme sebagai sebuah realitas. Berbeda dangan standar medis dimana normalisme didasarkan pada standarstandar mayoritas dan yang berbeda/minoritas dikatakan sebagai tidak normal, dalam konsepsi difabilitas standar kenormalan adalah realitas itu sendiri dimana manusia adalah sejatinya beragam. ${ }^{21}$

Setya Adi Purwanta, menegaskan bahwa dalam hal memberikan "label" terhadap sesuatu tidaklah dapat dilepaskan dari efek dari pelabelan tersebut. Penggunaan sebutan (label) itu dapat menimbulkan berbagai jenis dan intensitas keseriusan efeknya, misalnya penyebutan dapat berefek penghormatan, keakraban, kecintaan, merendahkan, penghinaan, dan bahkan diskriminasi. ${ }^{22}$

Pendekatan difabalitas secara epistemologi memiliki kesamaan paradigma dengan pendekatan sosial model. Dikonstruksi sebagai antitesis terhadap paradigma medical model. Paradigma difabilitas cenderung melihat manusia sebagai makhluk ciptakan Tuhan dengan derajat kesempurnaannya masingmasing. Dengan demikian, konsepsi difabilitas, sangat menghormati keberagaman latar belakang, kondisi, potensi, dan kemampuan setiap individu. Kondisi fisik yang berbeda merupakan instrumen yang dianugerahkan oleh Tuhan untuk menjalankan tugas hidupnya di dunia. Maka konsepsi difabilitas lebih melihat "keragaman" atau "perbedaan kemampuan" sebagai sebuah realitas objektif. Kecacatan dalam makna difabilitas, dipandang sebagai konstruksi sosial. Jika kecacatan dipahami sebagai konstruksi sosial berarti ia bukan realitas, melainkan

${ }^{20}$ Joni Yulianto, “Terminologi: Difabel atau Penyandang Disabilitas", dalam M.Syafi'ie, dkk, Potret Difabel Berhadapan dengan Hukum Negara, h. 15.

${ }^{21}$ Joni Yulianto, "Terminologi: Difabel atau Penyandang Disabilitas", dalam M.Syafi'ie, dkk, Potret Difabel Berhadapan dengan Hukum Negara, h. 15.

${ }^{22}$ Setya Adi Purwanta, "Bagaimana Aku menyebut Mereka? Penyandang Cacat, Disabilitas, atau Difabel", dalam http://komitedisabilitasdiy.blogspot.co.id, diakses: 3 Februari 2015. 
ia adalah bangunan sosial yang menghambat, dimana jika hambatan itu dihilangkan maka dengan sendirinya kecacatan akan terhapus.

Untuk itulah wacana difabilitas ini dihadirkan dalam wacana publik untuk melawan disabelisme. Bagi para pengkaji disabilitas tentu paham apa itu disabelisme. Ishak Salim, menjelaskan, disabelisme adalah pemahaman seseorang atau sekolompok orang dalam skala masyarakat maupun negara yang mengabaikan keberadaan dan keterlibatan orang lain hanya karena orang tersebut memiliki struktur dan fungsi tubuh dan mental yang berbeda dengan mayoritas atau masyarakat pada umumnya. Jika rasisme adalah pengucilan orang-orang tertentu dengan alasan karena memiliki ras yang berbeda, maka demikianlah cara disabelisme bekerja. Jadi, begitu memasuki pintu disabelisme ini maka akan bertemu ruang-ruang lain yang terkait dengan banyak sektor dalam kehidupan dimana praktik disablement atau pengabaian difabel bekerja atau berjalan dalam mayarakat. $^{23}$

Sebagian besar organisasi difabel tampil mendorong mainstreaming difabilitas dalam wacana publik. Salah satu yang bisa dilihat, adalah tindakan komunikatif kaum difabel dalam menyuarakan perlawanan melalui workshop dan seminar-seminar. Bahasan-bahasan dalam workshop tersebut bukan hanya untuk mengenali berbagai bentuk diskriminasi dan subordinasi warga difabel. Arahan untuk memahami lebih dalam bagaimana praktik tersebut bekerja dan menjadi cara pandang yang hegemonik.

Mansour Fakih seperti dikutip Ro'fah dan Slamet, yang memang sangat Gramcian, menilai bahwa, "cacat" merupakan konstruksi sosial. Cacat adalah sejenis pelabelan yang semena-mena dilekatkan oleh orang normal pada warga difabel. Mansour menegaskan, nalar developmentalisme yang memang selalu menghendaki kerapian dan ketertiban demi terciptanya pembangunan ekonomi yang diimpikan masyarakat kelas atas. ${ }^{24}$

\footnotetext{
${ }^{23}$ Ishak Salim, "Perspektif Disabilitas dalam Pemilu 2014 danKontribusi Gerakan Difabel Indonesia bagiTerbangunnya Pemilu Inklusif di Indonesia", h. 85.

${ }^{24}$ Ro'fah Mudzakir dan Slamet Thohari, 2010, "Kaum Difabel dalam Pergulatan Makna: Sekilas Pergeseran Persepsi Disability dan Relevansinya di Indonesia”, h. 87.
} 
Lanjut Mansour, pada dasarnya untuk memulai membongkar salah satu jenis ketidakadilan sosial, politik, budaya, dan ekonomi yang dialami oleh sebagian warga masyarakat yang sering disebut sebagai "penyadang cacat" justeru bermula dari keyakinan ideologis masyarakat, akademisi, birokrat tentang apa yang disebut penyandang cacat itu. Apa yang dianggap sebagai suatu realitas sosial penyadang cacat adalah dikonstruksi secara sosial.

Dengan kata lain apa yang dianggap sebagai suatu realitas mengenai "cacat" merupakan suatu kesepakatan sosial atau suatu konvensi sosial. Apa yang oleh suatu masyarakat diyakini di sekitar mereka yang mendapat label "cacat" dan "tidak cacat" adalah suatu konvensi sosial. Bahkan, mulai dari label "cacat" ini tersembunyi pengertian "baik" dan "tidak baik", bahkan tersembunyi juga "normal" dan "tidak normal". Konstruksi sosial atau konvensi sosial yang berlaku adalah bahwa mereka yang cacat adalah "tidak normal" dan mereka yang tidak cacat adalah "normal". ${ }^{25}$ Konsepsi keadilan yang dijelaskan oleh Mansour terhadap kaum-kaum difabel perlu diteletakkan pada tatanan yang proporsional, agar hak-hak kaum difabel dalam konsep sosial dimaknai baik.

\section{Landasan Yurdis dan Urgensi Pemenuhan Hak-hak Kaum Difabel dalam}

\section{Kerangka HAM}

\section{a. Landasan Yuridis Pemenuhan Hak-hak Kaum Difabel}

Berikut beberapa Undang-Undang yang berkaitan dengan jaminan perlidungan hak-hak difabel. Undang-Undang Dasar 1945 menjamin kesetaraan hak dan kesempatan setiap warga negara, termasuk warga negara difabel (khususnya lihat Pasal $28 \mathrm{H}$ ayat 2, dan Pasal 28 I ayat 2). UU No. 69 tahun 1999 tentang HAM (khususnya lihat Pasal 3, 5, dan 41), UU No. 13 tahun 2003 tentang Ketenagakerjaan (khususnya lihat Pasal 28), UU No. 23 tahun 2002 tentang Perlindungan Anak (khususnya lihat Pasal 8, 9, 11, 12, 13), UU No. 20 tahun 2003 tentang Sistem Pendidikan Nasional (khususnya lihat Pasal 5 dan 23). ${ }^{26}$

\footnotetext{
${ }^{25}$ Mansour Faqih, “Akses Ruang yang Adil: Meletakkan Dasar Keadilan Sosial bagi Kaum Difabel”, dalam Suharto dan Haris Munandar (ed.), Pokok-pokok Pikiran Dr. Mansour Fakih: Refleksi Kawan Seperjuangan (Yogyakarta: SIGAB, 2014), h. 167-168.

${ }^{26}$ Sunarman Sukamto, Best Practice Advokasi Kebijakan Daerah Perperspektif Difabel: Pengalaman PPRBM Solo (Solo: PPRBM Solo, t.th.), h. 2.
} 
Secara normatif, terdapat tiga peraturan perundang-undangan utama terkait dengan penyandang disabilitas di Indonesia: UU No. 4 tahun 1997 tentang Penyandang Cacat dan peraturan untuk pelaksanaannya, yaitu Peraturan Pemerintah No. 43 tahun 1998 (tentang Upaya Peningkatan Kesejahteraan Sosial Penyandang Cacat), ratifikasi CRPD ke dalam UU No. 19 Tahun 2011 Tentang Hak-Hak Penyadang Disabilitas, dan UU No. 8 Tahun 2016 tentang Penyandang Disabilitas. Akan tetapi, kurangnya perhatian dan masih adanya diskriminasi terhadap para penyandang disabilitas di Indonesia masih sangat dalam mengakar pada stigma serta persepsi yang tidak tepat terkait dengan kemampuan para penyandang disabilitas di dalam menjalankan kegiatan sehari-hari mereka, termasuk di dalamnya juga terkait dengan kontribusi yang mereka berikan secara aktif di semua sektor ekonomi. ${ }^{27}$

Khusus di negara berkembang seperti Indonesia, terabaikannya masalah "difabel” ini disebabkan oleh adanya faktor sosial budaya, selain faktor ekonomi dan lemahnya kebijakan dan penegakan hukum yang memihak komunitas difabel. $^{28}$ Adalah UU No. 4 Tahun 1997 Tentang Penyandang Cacat, bisa dianggap sebagai respon pemerintah atas wacana-wacana kesamaan hak bagi warga difabel yang telah menjadi agenda global. Seperti Undang-Undang anti diskriminasi difabel di belahan dunia lain, UU No. 4 Tahun 1997 ini bertujuan untuk menjamin kesamaan hak dan partisipasi difabel. Ada sedikitnya 10 Pasal dalam UU ini yang secara eksplisit menyatakan hak-hak difabel dan kesamaan partisipasi dalam pendidikan, pekerjaan, dan penyediaan aksesibilitas. ${ }^{29}$

Termasuk Convention on the Rights of Persons with Disabilities (selanjutnya disingkat CRPD) yaitu konvensi tentang Hak-hak Penyandang Disabilitas, telah diratifikasi oleh Negara Republik Indonesia dalam UndangUndang Negara Republik Indonesia Nomor 19 Tahun 2011 (selanjutnya disingkat

${ }^{27}$ Paper dipresentasikan dalam acara Lokakarya Pemetaan Kegiatan Disabilitas: ILO (PROPEL-Indonesia) \& World Bank (DPO Window) (Jakarta tanggal 26-27 September 2012), h. 5.

${ }^{28}$ Rahayu Repindowaty Harahap dan Bustanuddin, "Perlindungan Hukum Terhadap Penyandang Disabilitas MenurutConvention on the Rights of Persons With Disabilities (CRPD)," Jurnal Inovatif (Volume VIII, Nomor I, Januari 2015), h. 7.

${ }^{29}$ Ro'fah Mudzakir dan Slamet Thohari, h. 91. 
UU No. 19 Tahun 2011) tentang Pengesahan CRPD. CRPD merupakan instrument HAM internasional dan nasional dalam upaya Penghormatan, Pemenuhan dan Perlindungan Hak difabel di Indonesia (Developmenttool and Human Rights Instrument). Tujuan konvensi ini adalah untuk memajukan, melindungi, dan menjamin kesamaan hak dan kebebasan yang mendasar bagi semua penyandang disabilitas, serta penghormatan terhadap martabat penyandang disabilitas sebagai bagian yang tidak terpisahkan (inherent dignity). ${ }^{30}$

Ratifikasi CRPD oleh Pemerintah Indonesia adalah sebuah tindakan yang memberikan pergeseran mendasar dari pendekatan kesejahteraan sosial menjadi pendekatan hak asasi manusia.Termasuk di dalamnya adalah untuk memfokuskan pada penghalang-penghalang yang menghambat di lingkungan fisik, sosial, budaya dan ekonomi sehingga para penyandang disabilitas bisa berpartisipasi dan memberikan kontribusi mereka sesuai dengan kemampuan yang mereka miliki. Terlebih lagi, pendekatan ini juga menerima pemikiran untuk mengadopsi perundang-undangan dan kebijakan non diskriminatif. ${ }^{31}$

CRPD menetapkan hak-hak penyandang disabilitas secara luas yaitu setiap penyandang disabilitas harus bebas dari penyiksaan atau perlakuan yang kejam, tidak manusiawi, merendahkan martabat manusia, bebas dari eksploitasi, kekerasan dan perlakuan semena-mena, serta memiliki hak untuk mendapatkan penghormatan atas integritas mental dan fisiknya berdasarkan kesamaan dengan orang lain. CRPD juga menetapkan kewajiban umum setiap Negara peserta disamping kewajiban-kewajiban lain yang ditetapkan secara eksplisit dan rinci. Negara wajib mengadopsi semua kebijakan legislatif dan administratif sesuai dengan Konvensi ini. Artinya, seluruh Peraturan Perundang-undangan yang berlaku positif di Indonesia serta peraturan dibawahnya haruslah disesuaikan serta disinkronikasikan sesuai dengan konvensi ini, mulai dari substansi di dalam Perundang-undangannya hingga sampai klausul-klausul pasalnya. ${ }^{32}$

\footnotetext{
${ }^{30}$ Rahayu dan Bustanuddin, h. 19.

${ }^{31}$ Paper di Presentasikan dalam acara Lokakarya Pemetaan Kegiatan Disabilitas: ILO (PROPEL-Indonesia) \& World Bank (DPO Window) (Jakarta tanggal 26-27 September 2012), h. 5.

${ }^{32}$ Paper di Presentasikan dalam acara Lokakarya Pemetaan Kegiatan Disabilitas, h. 7.
} 
Pelaksanaan kewajiban tersebut, Negara harus mengacu pada prinsipprinsip umum yakni; Penghormatan pada martabat yang melekat, otonomi individual, termasuk kebebasan untuk menentukan pilihan, dan kemerdekaan perseorangan; (1) Nondiskriminasi; (2) Partisipasi penuh dan efektif dan keikutsertaan dalam masyarakat; (3) Penghormatan atas perbedaan dan penerimaan penyandang disabilitas sebagai bagian dari keragaman manusia dan kemanusiaan; (4) Kesetaraan kesempatan; (5) Aksesibilitas; (6) Kesetaraan antara laki-laki dan perempuan. ${ }^{33}$

Selain itu, Negara Republik Indonesia adalah negara yang berdasarkan Pancasila dan Undang-Undang Dasar Negara Republik Indonesia Tahun 1945 yang menghormati dan menjunjung tinggi harkat dan martabat manusia sehingga perlindungan dan pemajuan hak asasi manusia terhadap kelompok rentan khususnya penyandang disabilitas perlu ditingkatkan. Hal ini terlihat dalam Pasal 5 ayat (1), Pasal 11, Pasal 20, dan Pasal 28 I ayat (2) Undang-Undang Dasar Negara Republik Indonesia Tahun 1945. ${ }^{34}$

Secara etik-filosofis, konsepsi difabilitas memiliki relevansi dengan falsafah Pancasila, dengan semboyan "Bhineka Tunggal Ika" yang berarti berbeda-beda tapi satu tujuan. Ini menunjukkan bahwa Negara Indonesia pada prinsipnya memiliki nilai-nilai yang menghargai keragaman, keberbedaan, serta pluralitas. Maka secara kritis dapat dikatakan bahwa apabila masyarakat dan pemerintah selaku pemangku kebijakan publik tidak menghargai keberadaan difabel yang notabene sebagai bagian dari keragaman warga negara, maka sesungguhnya telah menodai Pancasila sebagai dasar dan falsafah negara. Pancasila yang berorientasi pada keragaman dan pluralitas, seyogyanya tidak hanya diinternalisasikan dalam diri individu masyarakat, melainkan seharusnya di transformasikan ke dalam tindakan sosial, dalam kehidupan berbangsa dan bernegara. Ini penting, agar proses pengambilan kebijakan publik juga memperhatikan aspek-aspek difabilitas.

26.

\footnotetext{
${ }^{33}$ Paper di Presentasikan dalam acara Lokakarya Pemetaan Kegiatan Disabilitas, h. 25-
}

${ }^{34}$ Paper di Presentasikan dalam acara Lokakarya Pemetaan Kegiatan Disabilitas, h. 18. 


\section{b. Urgensi Pemenuhan Hak-hak Kaum Difabel}

Menurut Deklarasi Universal Hak Asasi Manusia Internasional (DUHAM) 1948 setiap orang berhak atas hak dan kebebasan dengan tidak ada pengecualian seperti perbedaan ras, warna kulit, jenis kelamin, agama, bahasa, politik, atau pandangan lain, asal usul kebangsaan. Sedangkan menurut UU No 39 Tahun 1999, HAM adalah seperangkat hak yang melekat pada hakekat keberadaan manusia sebagai makhluk Tuhan YME dan merupakan anugerahnya yang harus dihormati, dijunjung tinggi dan dilindungi oleh negara, hukum, pemerintah dan setiap orang demi kehormatan serta perlindungan harkat dan martabat manusia. ${ }^{35}$

Pemahaman seperti itu, maka penghormatan, perlindungan, dan pemenuhan HAM terhadap warga negara harus dijamin dalam peraturan perundang-undangan yang berlaku di Indonesia. Ruang lingkup warga negara dalam hal ini luas, mencakup siapapun tanpa terkecuali sebagaimana diatur dalam Pasal 25 ayat (1) UUD 1945, termasuk di dalamnya penyandang disabilitas. Penegasan mengenai lingkup itu sangat penting, karena HAM bagi penyandang disabilitas masih kerap diabaikan, bahkan dilanggar. Pelanggaran terjadi karena penyandang disabilitas tidak dianggap sebagai bagian dari warga negara, bahkan juga tidak dianggap manusia. ${ }^{36}$

Salah satu bentuk negara terkait upaya penghormatan, perlindungan, dan pemenuhan hak difabel adalah sikap pemerintah Indonesia yang terlibat secara proaktif dalam mengadopsi instrument HAM bagi difabel. Komitmen tersebut ditunjukkan kesepekatan Indonesia untuk menjadi salah satu negara penandatangan Convention On The Rights Of Persons With Disabilities (CRPD) pada 30 Maret 2007. Ratifikasi tersebut merupakan sebuah momentum penting untuk meningkatkan harkat dan martabat difabel. ${ }^{37}$

\footnotetext{
${ }^{35}$ Tim Kontras, Panduan untuk Pekerja HAM: Pemantaun dan Inevetigasi Hak Asasi Manusia (Kontras, 2009), h. 29-31.

${ }^{36}$ Fajri Nursyamsi, dkk, Kerangka Hukum Disabilitas Di Indonesia: Menuju Indonesia Ramah Disabilitas (Jakarta: Pusat Studi Hukum dan Kebijakan Indonesia (PSHK), 2015), h. 9.

${ }^{37}$ Faiq Tobrani, "Rekonstruksi Kelembagaan atas Hak Dasar Difabel yang lumpuh di Indonesia", dalam Kamil Alfi Arifin (Ed.), Analekta Disabilitas: Sumbangsi untuk Pengayaan Rancangan Undang-undang Disabilitas (Jurnal Difabel, Vol. 2, No. 2, 2015), h. 352.
} 
Semangat penghormatan, pemajuan, perlindungan, pemberdayaan, penegakan, dan pemenuhan hak-hak difabel yang termuat dalam CRPD mengacu sepenuhnya pada prinsip Hak Azasi Manusia. ${ }^{38}$ Berikut beberapa bentuk pengakuan, perlindungan, dan pemenuhan hak-hak difabel dalam bagian pembukaan konvensi tersebut:

a) Mengakui bahwa disabilitas merupakan suatu konsep yang terus berkembang dan disabilitas merupakan hasil dari interaksi antara orang-orang dengan keterbatasan kemampuan dan sikap dan lingkungan yang menghambat partisipasi penuh dan efektif mereka di dalam masyarakat berdasarkan kesetaraan dengan yang lainnya,

b) Mengakui pentingnya pedoman prinsip-prinsip dan kebijakan yang termuat dalam Program Aksi Dunia mengenai Penyandang Disabilitas (World Programme of Action concerning Disabled Persons) dan Peraturan-peraturan Standar mengenai Persamaan Kesempatan bagi Penyandang Disabilitas (Standard Rules on the Equalization of Opportunities for Persons with Disabilities);

c) Menekankan pentingnya pengarusutamaan isu-isu disabilitas sebagai bagian integral dari strategi yang relevan bagi pembangunan yang berkesinambungan,

d) Mengakui juga bahwa diskriminasi atas setiap orang berdasarkan disabilitas merupakan pelanggaran terhadap martabat dan nilai yang melekat pada setiap orang,

e) Mengakui pula keragaman penyandang disabilitas.

f) Mengakui perlunya memajukan dan melindungi hak asasi manusia semua penyandang disabilitas, termasuk mereka yang memerlukan dukungan intensif yang lebih. 39

Selanjutnya Pasal 5 konvensi menekankan persamaan dan non-diskriminasi:

1. Negara-Negara Pihak mengakui bahwa semua manusia adalah sama di hadapan dan di bawah hukum dan berhak, tanpa diskriminasi, untuk mendapatkan perlindungan dan manfaat hukum yang sama;

2. Negara-Negara Pihak wajib mencegah semua diskriminasi yang difundamentalkan disabilitas serta menjamin perlindungan hukum yang sama dan efektif bagi penyandang disabilitas terhadap dikriminasi dengan fundamental alasan apa pun;

3. Dalam rangka memajukan persamaan dan menghapuskan diskriminasi, Negara Pihak wajib mengambil Iangkah-Iangkah yang Iayak untuk menjamin bahwa penyesuaian-penyesuaian yang beralasan diberikan;

\footnotetext{
${ }^{38}$ Faiq Tobrani, "Rekonstruksi Kelembagaan atas Hak Dasar Difabel yang lumpuh di Indonesia", h. 353.

${ }^{39}$ Lihat bagian Pembukaan Konvensi Hak-hak Penyandang Disabilitas (Convention On The Rights Of Persons With Disabilities (CRPD).
} 
4. Langkah-Iangkah khusus yang diperlukan untuk mempercepat atau mencapai persamaan bagipenyandang disabilitas secara de facto tidak boleh dianggap sebagai diskriminasi di bawah Konvensi ini; ${ }^{40}$

Sebagaimana dalam dua dasawarsa terakhir, masyarakat penyandang disabilitas global telah berusaha untuk memerangi pandangan terhadap isu disabilitas atau penyandang disabilitas sebagai objek kegiatan amal atau orang sakit yang membutuhkan kesembuhan. Mereka juga berusaha untuk mendefinisi ulang penyandang disabilitas sebagai anggota penuh dan setara dari masyarakat, yang memiliki kontribusi penting dalam keluarga dan masyarakatnya. Pemikiran yang telah berubah ini, menekankan bahwa kesempatan penyandang disabilitas dalam mencapai potensi penuh mereka bukan terhalang oleh kelemahan atau kekurangan mereka, namun oleh perilaku tidak sehat dan tidak mendukung dari masyarakat, serta hambatan-hambatan sosial para penyandang disabilitas.

Untuk mewujudkan agenda pemenuhan hak-hak difabel dalam kerangka hak azasi manusia, menurut Mansour Fakih, perlu dipikirkan beberapa usaha sosial: Pertama, perlu mendidik kasadaran manusia "normal" akan hak azasi difabel kepada setiap individu di setiap rumah tangga, sampai pada kebijakan pembangunan negara melalui badan-badan pemerintah. Secara lebih kongkret misalnya implikasi dari ratifikasi UU penyandang disabilitas dalam perencanaan pembangunan. Tidak hanya pengorganisasian kaum difabel, melainkan juga bangkitnya gerakan terhadap kaum difabel (kaum difabel movement) bagi gerakan NGOs yang sudah ada. Hal ini karena tegaknya hak azasi difabel tidaklah merupakan hadiah dari negara, melainkan harus diperjuangkan oleh kaum difabel sendiri. $^{41}$

Kedua, gerakan untuk menciptakan kota yang ramah terhadap kaum difabel terutama seluruh fasilitas publik. Ini berarti membalik cara berpikir dominan bahwa jika seseorang yang duduk di atas kursi roda dan tidak bisa beribadah di tempat ibadah karena tidak ada tangga (jalan khusus) dan akses

${ }^{40}$ Lihat pasal 5 Konvensi Hak-hak Penyandang Disabilitas (Convention On The Rights Of Persons With Disabilities CRPD).

${ }^{41}$ Mansour Fakih, "Akses Ruang yang Adil Meletakkan Dasar Keadilan Sosial bagi Kaum Difabel”, dalam Suharto dan Aris Munandar (Ed.), Pokok-pokok Pikiran Dr. Mansour Fakih: Refleksi Kawan Seperjuangan (Yogyakarta: SIGAB, 2004), h. 179. 
terhadap difabel, maka yang dipersalahkan janganlah kaum difabel, melainkan perlu introspeksi akan adanya diskiriminasi dalam arsitektur bangunan tersebut. Demikian halnya jika kaum difabel tidak mampu memasuki arena politik, ekonomi, dan budaya, yang perlu dipersalahkan bukanlah kaum difabel yang menjadi "victim" dari sistem yang diskriminatif tersebut. ${ }^{42}$

Ketiga, gerakan mengenai bagaimana proses diseminasi ideologi kritis tentang kaum difabel pada setiap program dan kebijakan kelembagaan dan keorganisasian, baik lembaga pemerintah, pendidikan, program kemasyarakatan, maupun keagamaan, bahkan kalangan NGOs. Masuk dalam agenda ini kajian bagaimana melakukan pendidikan sensitifitas difabel pada para pengambil keputusan, melakukan pengawasan dan kritik terhadap kebijakan dan praktik organisasi pemerintah maupun NGOs yang bias terhadap kaum difabel. ${ }^{43}$ Keempat, dikemudian hari perlu usaha yang lebih bersifat law inforcement. Usaha ini termasuk melakukan audit diskriminasi terhadap kaum difabel, monitoring dan evaluasi terhadap proses, ataupun projek dan institusi pembangunan sosial yang masih melanggengkan diskriminasi terselubung kaum difabel, serta usaha-usaha advokasi terhadap perubahan kebijakan yang lebih ramah terhadap difabel. ${ }^{44}$

Semestinya permasalahan kaum difabel tidak hanya diselesaikan dengan pendekatan yang bersifat social based, dengan memandang pemenuhan hak-hak difabel sebatas sebagai sebuah masalah social. Melainkan harus melihat permasalahan difabel dalam sudut pandang yang lebih holistik dan terintegrasi.

Faiq Tabroni menyampaikan hal senada, bahwa "Pengaturan pemenuhan hak difabel cenderung lebih bersifat sosial menimbulkan berbagai permasalahan. Salah satunya melahirkan sudut pandang bahwa sektor lain seperti kesehatan, pendidikan, dan ketenagakerjaan yang diatur dalam UU No. 4 Tahun 1997 tentang Penyandang Cacat, lebih berfungsi sebagai sektor penunjang dalam pelaksanaan

\footnotetext{
${ }^{42}$ Mansour Fakih, “Akses Ruang yang Adil Meletakkan Dasar Keadilan Sosial bagi Kaum Difabel", h. 179-180.

${ }^{43}$ Mansour Fakih, "Akses Ruang yang Adil Meletakkan Dasar Keadilan Sosial bagi Kaum Difabel", h. 180.

${ }^{44}$ Mansour Fakih, “Akses Ruang yang Adil Meletakkan Dasar Keadilan Sosial bagi Kaum Difabel", h. 180.
} 
pemenuhan hak difabel. Pola pikir semacam itu tentu saja menyebabkan pemenuhan hak difabel di luar masalah sosial kurang tersentuh. Selama satu dekade terakhir, masih terdengar adanya praktik diskrimanatif terhadap difabel di luar jaminan kesejahteraan social, sebagai contoh, bidang pendidikan. Kecacatan (impairment) bisa menyebabkan difabel seringkali mengalami penolakan dan hambatan terhadap akses memperoleh pendidikan dari lembaga pendidikan. ${ }^{45}$

Hadirnya UU No. 8 Tahun 2016 tentang penyandang cacat adalah bagian dari upaya peningkatan perlindungan hak-hak kaum difabel. Karena selama ini UU No. 4/1997 dirasa kurang mampu menyelesaikan persoalan difabel secara holistik dan integral. Maka dibutuhkan suatu lembaga khusus untuk menangani permasalahan difabel, yang tidak hanya melihat permasalahan difabel dari sudut pandang pemenuhan kesejahteraan sosial, melainkan lebih jauh harus melihat seluruh aspek persoalan difabel baik dari sisi sosial, maupun dari sisi kesehatan, pendidikan, politik, dan budaya termasuk dalam hal ini adalah agama. Mungkin lembaga itu bisa berupa Komisi Perlindungan Hak-hak Kaum Difabel (KPHD).

\section{PENUTUP}

Pemenuhan hak-hak kaum difabel semestinya tidak hanya dipandang dari sisi kesejahteraan sosial dalam wujud belas kasih, dengan memandang permasalahan difabel sebatas sebagai permasalahan sosial, melainkan pemenuhan hak-hak harus memuat berbagai sektor di dalam kehidupan publik. Pemenuhan hak-hak kaum difabel dalam akses pendidikan, kesehatan, ekonomi, pekerjaan, politik, budaya, dan agama. Artinya pemenuhan hak-hak difabel dilakukan secara holistik dan integral, di samping pemenuhan hak-hak yang berbasis kebutuhan, juga mempertimbangkan aspek akses dan kesempatan yang dibuka pada semua sektor kehidupan. Selain itu, untuk menguatkan posisi kaum difabel dalam arena publik, semestinya ada lembaga khusus berupa Komisi Perlidungan Hak-hak Kaum Difabel (KPHD) untuk menyeselaikan berbagai kompleksitas permasalahan difabel baik dari sisi sosial, budaya, pendidikan, hukum, maupun politik.

\footnotetext{
${ }^{45}$ Faiq Tobrani, "Rekonstruksi Kelembagaan atas Hak Dasar Difabel yang lumpuh di Indonesia”, h. 350.
} 


\section{DAFTAR PUSTAKA}

Michel Foucault, 2012, Arkeologi Pengetahuan, terj. Inyiak Ridwan Muzir, Yogyakarta: IRCiSoD.

Yasraf A. Piliang, 2005, Transpolitika: Dinamikan Politik di dalam Era Virtualitas, Yogyakarta: Jalasutra.

Benny H. Hoed, 2011, Semiotik dan Dinamika Sosial Budaya, Depok: Komunitas Bambu.

Majda El Muhtaj, 2009, Dimensi-dimensi HAM: Mengurai Hak Ekonomi, Sosial, dan Budaya, Jakarta: Rajawali Pers.

Tim Kontras, 2009, Panduan untuk Pekerja HAM: Pemantaun dan Inevetigasi Hak Asasi Manusia, Kontras.

Fajri Nursyamsi, dkk, 2015, Kerangka Hukum Disabilitas Di Indonesia: Menuju Indonesia Ramah Disabilitas, Jakarta: Pusat Studi Hukum dan Kebijakan Indonesia (PSHK).

Mansour Faqih, 2014, “Akses Ruang yang Adil: Meletakkan Dasar Keadilan Sosial bagi Kaum Difabel”, dalam Suharto dan Haris Munandar (ed.), Pokok-pokok Pikiran Dr. Mansour Fakih: Refleksi Kawan Seperjuangan, Yogyakarta: SIGAB.

Joni Yulianto, 2014, "Terminologi: Difabel atau Penyandang Disabilitas", dalam M.Syafi'ie, dkk, Potret Difabel Berhadapan dengan Hukum Negara, Yogyakarta: sigab

Ishak Salim, "Perspektif Disabilitas dalam Pemilu 2014 danKontribusi Gerakan Difabel Indonesia bagiTerbangunnya Pemilu Inklusif di Indonesia”, Jurnal The Politics, Vol. 1, No. 2, Juli 2015.

Ro'fah, “Teori Disabilitas: Sebuah Review Literatur" dalam Kamil Alfi Arifin (ed.), Analekta Difabilitas: Sumbangsih untuk Pengayaan Rancangan Undang-undang Difabilitas, Jurnal DIFABEL, Sasana Integrasi dan Advokasi Difabel (SIGAB), Vol. 2, No. 2, Tahun 2015.

Ro'fah Mudzakir dan Slamet Thohari, 2010, “Kaum Difabel dalam Pergulatan Makna: Sekilas Pergeseran Persepsi Disability dan Relevansinya di Indonesia", dalam Sahiron dan Asep Jahidin (ed.), Ontologi Pekerjaan Sosial, Yogyakarta: UIN Sunan Kalijaga.

Asyhabuddin, "Difabilitas dan Pendidikan Inklusif: Kemungkinannya di STAIN Purwokerto," Jurnal INSANIA, P3M STAIN Purwokerto, Vol. 13, No. 3, Sep-Des 2008.

Sunarman Sukamto, Best Practice Advokasi Kebijakan Daerah Perperspektif Difabel: Pengalaman PPRBM Solo, Solo: PPRBM Solo. 
Paper dipresentasikan dalam acara Lokakarya Pemetaan Kegiatan Disabilitas: ILO (PROPEL-Indonesia) \& World Bank (DPO Window), Jakarta tanggal 26-27 September 2012.

Rahayu Repindowaty Harahap dan Bustanuddin, "Perlindungan Hukum Terhadap Penyandang Disabilitas MenurutConvention on the Rights of Persons With Disabilities (CRPD)," Jurnal Inovatif, Volume VIII, Nomor I, Januari 2015.

Paper di Presentasikan dalam acara Lokakarya Pemetaan Kegiatan Disabilitas: ILO (PROPEL-Indonesia) \& World Bank (DPO Window), Jakarta tanggal 26-27 September 2012. 